\title{
TANGGUNG JAWAB DEVELOPER PERUMAHAN TERHADAP PENYEDIAAN TEMPAT PEMAKAMAN
}

\begin{abstract}
Oleh:
Andi Pontjo Wiyono

Abstract

Housing is one of the basic needs for human beings. For most people of Indonesia, the word "home" becomes a necessity that is very expensive, but the house is a basic need, fundamentals, and also a prerequisite for everyone to survive and live and enjoy life dignified, peaceful, safe, and comfortable. it is the responsibilityDeveloper Housing Provision Against Cemetery to support public facilities.
\end{abstract}

key words: Responsibilities Developer Housing Provision Of Cemetery

\section{A. PENDAHULUAN}

Tujuan dan cita-cita perjuangan bangsa Indonesia adalah terwujudnya masyarakat yang adil dan makmur berdasarkan Pancasila dan Undang-Undang Dasar tahun 1945, seiring dengan tujuan pembangunan nasional adalah mewujudkan kesejahteraan lahir dan batin bagi seluruh rakyat Indonesia secara adil dan merata. Salah satu unsur pokok kesejahteraan rakyat adalah terpenuhinya kebutuhan perumahan, yang merupakan kebutuhan dasar bagi setiap warga Negara Indonesia dan keluarganya, sesuai dengan harkat dan martabatnya sebagai manusia.Tanah adalah sumber daya alam terpenting sekarang ini, di saat populasi manusia terus meningkat sementara luasnya tidak bertambah. Tidak hanya sebagai tempat membangun rumah tinggal, dari tanah juga didapatkan bahan makanan, pakaian, dan kebutuhan lainnya yang bersifat primer. ${ }^{1}$ Perumahan merupakan salah satu kebutuhan dasar bagi manusia. Bagi sebagian besar masyarakat Indonesia, kata "rumah" menjadi suatu kebutuhan yang sangat mahal, padahal rumah adalah suatu kebutuhan dasar, fundamental, dan sekaligus prasyarat bagi setiap orang untuk bertahan dan hidup serta menikmati kehidupan bermartabat, damai, aman, dan nyaman. Dengan kata lain, dampak negatif terbuka pada individu yang tidak mempunyai rumah tinggal. Lebih jauh, tanpa mempunyai akses perumahan, kehidupan pribadi, maupun sosial akan sulit dicapai. ${ }^{2}$

\footnotetext{
${ }^{1}$ Soimin Soedharyo, Status Hak dan Pembebasan Tanah, PT. Sinar Grafika, Jakarta, 2008, hlm 12

2 Patra M. Zein, Hak Atas Perumahan, PT. Citra Adithya Bakti, Jakarta, 2004, hlm 74.
} 
Sejalan dengan pertumbuhan penduduk yang makin pesat, tuntutan akan tersedianya berbagai fasilitas yang mendukung kehidupan masyarakat juga mengalami peningkatan. Setiap individu selalu berkeinginan agar rumah yang dihuninya memenuhi standar kesehatan, standar konstruksi, tersedianya fasilitas umum, fasilitas sosial dan prasarana lingkungan yang memadai. Makam merupakan salah satu komponen pembentuk ruang kota dan fasilitas yang harus disediakan oleh pengembang. Tetapi pengembang tidak menyediakan makam di kawasan perumahan, sebab warga sekitar perumahan menolak. ${ }^{3}$

Tempat pemakaman umum berdasarkan pasal 1 huruf a Peraturan Pemerintah Nomor 9 tahun 1987 tentang Penyediaan Penggunaan Tanah Untuk Keperluan Tempat Pemakaman (PP No. 9/1987) adalah area tanah yang disediakan untuk keperluan pemakaman jenazah bagi setiap orang tanpa membedakan agama dan golongan, yang pengelolaannya dilakukan oleh Pemerintah Daerah tingkat II atau Pemerintah Desa.

Selain dalam PP No. 9/1987, penyedia pemakaman juga diatur dalam Peraturan Menteri Dalam Negeri No. 9 tahun 2009 tentang Pedoman Penyerahan Prasarana, Sarana, dan Utilitas Perumahan dan Pemukiman di Daerah (Permendag 9/2009). Berdasarkan pasal 7 jo. Pasal 4 Permendag 9/2009, pemukiman dan perumahan dilengkapi dengan prasarana, sarana, dan utilitas. Yang dimaksud dengan perumahan dan pemukiman adalah perumahan yang bersusun dan perumahan susun.

Yang termasuk sarana perumahan dan pemukiman yaitu:

1. Sarana Perniagaan / Perbelanjaan;

2. Sarana pelayanan umum dan pemerintahan;

3. Sarana pendidikan;

4. Sarana kesehatan;

5. Sarana peribadatan;

6. Sarana rekreasi dan olah raga;

7. Sarana pemakaman;

8. Sarana pertamanan dan ruang terbuka hijau;

9. Sarana parkir. ${ }^{4}$

Pada dasarnya, ketersediaan sarana perumahan tersebut merupakan kewajiban penyelenggara pembangunan perumahan dan pemukiman. ${ }^{5}$ Hal ini dapat dilihat dalam Undang-Undang Nomor 1 tahun 2011 tentang Perumahan dan Kawasan Pemukiman. Dalam pasal 19 Undang-Undang Nomor 1 tahun 2011 dinyatakan bahwa penyelenggaraan rumah dan perumahan dilakukan untuk memenuhi kebutuhan rumah sebagai salah satu kebutuhan dasar manusia bagi

\footnotetext{
3 Mursalim, Perencanaan dan Pembuatan Fasilitas Perumahan, PT. Citra Adithya Bakti, Jakarta, 2002, hlm 84.

${ }^{4}$ Ibid.

5 Ajiraksa, Perencanaan dan Pengembang perumahan, PT. Citra Aditya Bakti, Jakarta, 2002, hlm 182
} 
peningkatan dan pemerataan kesejahteraan rakyat. Penyelenggaraan rumah dan perumahan dilaksanakan oleh Pemerintah, Pemerintah Daerah, dan/atau setiap orang yang menjamin hak setiap warga negara untuk menempati, menikmati, dan/atau memiliki rumah yang layak dalam lingkungan yang sehat, aman, serasi, dan teratur. ${ }^{6}$

\section{PEMBAHASAN}

\section{A. TANGGUNG JAWAB PENGEMBANG PERUMAHAN TERHADAP PENYEDIAAN FASILITAS UMUM TEMPAT PEMAKAMAN SUDAH SESUAI}

Perumahan adalah kelompok rumah yang berfungsi sebagai lingkungan tempat tinggal hunian yang dilengkapi dengan prasarana lingkungan yaitu kelengkapan dasar fisik lingkungan, misalnya penyediaan air minum, pembuangan sampah, tersedianya listrik, telepon, jalanan, yang memungkinkan lingkungan pemukiman berfungsi sebagaimana mestinya. Rumah adalah tempat untuk melepaskan lelah, tempat bergaul, dan membina rasa kekeluargaan diantara anggota keluarga, tempat berlindung keluarga dan menyimpan barang berharga. Rumah adalah struktur fisik yang terdiri dari ruangan, halaman dan area sekitarnya yang dipakai sebagai tempat tinggal dan sarana pembinaan keluarga (UU RI. NO. 1 Tahun 2011).

Menurut WHO (World Health Organization), rumah adalah struktur fisik atau bangunan tempat berlindung, di mana lingkungan berguna untuk kesehatan jasmani dan rohani serta keadaan sosialnya, baik untuk kesehatan keluarga dan individu (Komisi WHO mengenai kesehatan dan lingkungan, 2001).

Berdasarkan Undang-Undang No. 1 Tahun 2011 tentang Perumahan dan Pemukiman, terdapat beberapa pengertian dasar, yaitu:

- Rumah adalah bangunan yang berfungsi sebagai tempat tinggal atau hunian dan sarana pembinaan keluarga.

- $\quad$ Perumahan adalah kelompok rumah yang berfungsi sebagai lingkungan tempat tinggal atau lingkungan hunian yang dilengkapi dengan prasarana dan sarana lingkungan.

- $\quad$ Permukiman adalah satuan kawasan perumahan lengkap dengan prasarana lingkungan, prasarana umum, dan fasilitas sosial yang mengandung keterpaduan kepentingan dan keelarasan pemanfaatan sebagai lingkungan kehidupan.

- Prasarana adalah kelengkapan dasar fisik lingkungan hunian yang memenuhi standar tertentu untuk kebutuhan bertempat tinggal yang layak, sehat, aman, dan nyaman.

\footnotetext{
$6 \quad$ Soedjajadi Keman, Kesehatan Perumahan dan dan Lingkungan Pemukiman, Jurnal Kesehatan Lingkungan, Fakultas Kesehatan Masyarakat Univ. Airlangga, Vol.2, No. 1, Surabaya, 2005, hlm.30
} 
- $\quad$ Sarana adalah fasilitas dalam lingkungan hunian yang berfungsi untuk mendukung penyelenggaraan dan pengembangan kehidupan sosial, budaya, dan ekonomi.

- $\quad$ Utilitas umum adalah kelengkapan penunjang untuk pelayanan lingkungan hunian.

Menurut Suparno Sastra M. dan Endi Marlina, pengertian mengenai perumahan adalah sekelompok rumah yang berfungsi sebagai lingkungan tempat tinggal atau lingkungan hunian yang dilengkapi dengan prasarana dan dan sarana lingkungan. ${ }^{7}$

Sedangkan permukiman menurut Suparno Sastra M. dan Endi Marlina, adalah suatu tempat bermukim manusia untuk menunjukkan suatu tujuan tertentu. Apabila dikaji dari segi makna, permukiman berasal dari terjemahan kata settlements yang mengandung pengertian suatu proses bermukim. Pemukiman memiliki arti yang berbeda yaitu:

a) Isi. yaitu menunjuk pada manusia sebagai penghuni maupun masyarakat di lingkungan sekitarnya.

b) Wadah. Yaitu menunjuk pada fisik hunian yang terdiri dari alam dan elemen-elemen buatan manusia. ${ }^{8}$

Menurut pasal 5 tahun 1974 disebutkan pengertian Perusahaan Pembangunan Perumahan yang dapat pula masuk dalam pengertian Pengembang Perumahan, yaitu: "Perusahaan Pembangunan Perumahan adalah suatu perusahaan yang berusaha dalam bidang pembangunan perumahan dari berbagai jenis dalam jumlah yang besar di atas suatu areal tanah yang akan merupakan suatu kesatuan lingkungan pemukiman yang dilengkapi dengan prasarana-prasarana lingkungan dan fasilitas-fasilitas social yang diperlukan oleh masyarakat penghuninya". Dalam Undang - Undang perlindungan konsumen Pengembang Perumahan masuk dalam kategori sebagain pelaku usaha. Pengertian Pelaku Usaha dalam Pasal 1 angka 3 Undang - Undang No. 8 tahun 1989 tentang perlindungan konsumen yaitu: "Pelaku usaha adalah setiap orang atau perseorangan atau badan usaha, baik yang berkedudukan atau melakukan kegiatan dalam wilayah hokum Negara Republik Indonesia, baik sendiri maupun bersama-sama melaui perjanjian menyelenggarakan kegiatan usaha dalam berbagai bidang ekonomi".

Dalam Undang-Undang No.1 tahun 2011 tentang Perumahan dan Kawasan Permukiman (UU No.1/2011) pengembang perumahan masuk dalam kategori penyelenggara atau pengembang pembangunan perumahan dan pemukiman yang penyelenggaraan rumah dan perumahan dilalaksanakan oleh Pemerintah, Pemerintah Daerah dan/atau setiap orang untuk menjamin hak setiap warga Negara untuk menempati, menikmati, dan/atau memiliki rumah yang layak dalam lingkungan yang sehat, aman, serasi, dan teratur.

\footnotetext{
7 Didik Rianto, Perencanaan dan Pembangunan perumahan, PT.Tabah Jaya, Surabaya, 2006, hal. 29

8 Ibid., hlm. 37
} 
Dimulai dengan tahap perencanaan, pada tahap ini meliputi izin lokasi, izin perencanaan, IMB, serta bagaimana status tanah tempat fasilitas sosial direncanakan. Aspek pengawasan pada tahap perencanaan saat pengembang mengajukan izin pembangunan kompleks perumahan merupakan tahap pengendalian awal. Pengendalian ini diharapkan nantimya dalam tahap pembangunan dapat sesuai dengan apa yang diajukan sesuai dengan rencana/perizinan yang didapat.

Kemudian dilanjutkan pada tahap pembangunan yang mana pada tahap ini tanah dimatangkan dan diatasnya dibangun rumah dan fasilitas-fasilitasnya sebagaimana yang dinyatakan dalam rencana proyek yang telah disetujui. Dalam tahap ini peran Pemerintah Daerah dalam mengawasi pembangunan perumahan dan fasilitas sosial agar sesuai standar dan peraturan yang berlaku sangatlah besar. Pelaksanaan pengawasan dan pengendalian ini dilaksanakan oleh dinas PU dan instansi terkait secara berkelanjutan agar pelanggaran terhadap pembangunan fasilitas sosial dan fasilitas umum dapat dihindari.

Tahap selanjutnya, yaitu tahap penyerahan. Pada tahap penyerahan ini harus sesuai dengan Peraturan Menteri Dalam Negeri No. 9 tahgun 2009 tentang penyerahan Prasarana, sarana, dan Utilitas Perumahan dan Permukiman ke Pemda.. Setelah dilakukan tahap penyerahan sarana, prasarana, dan utilitas umum dari pengembang kepada Pemda, pengembang sudah tidak bertanggung jawab lagi atas kelangsungannya, baik pembiayaan atau pemeliharaan. Segala tanggung jawab sepenuhnya telah berada di pihak penghuni dan Pemda. Selanjutnya apabila ada pengembang, badan usaha swasta dan masyarakat yang ingin melakukan kerjasama untuk pengelolaan fasilitas yang telah diserahkan kepada Pemda untuk keperluan melanjutkan pembangunan perumahannya, seperti diatur dalam Permendagri pasal 22 ayat (3) No. 9 tahun 2009 maka diwajibkan memperbaiki dan memelihara fasilitas tersebut sehingga pemeliharaan dan pendanaan fasilitasfasilitas tersebut menjadi tanggung jawab pengelola.

Pembiayaan dalam pembangunan fasilitas sosial seperti diatur dalam Permendagri No. 9 tahun 2009 adalah dibebankan pada harga rumah. Untuk itu pengembang dapat menyediakan fasilitas sosial tyersebut tanpa harus menanggung kerugian yang berarti. Pada hakikatnya, pengembang hanya berkewajiban menyerahkan tanah matang pada Pemda dan Pemda melalui dinas terkait yang akan membangun fasilitas sosial tersebut.

Pemerintah Daerah (Pemda) meminta kepada pengembang untuk menyerahkan prasarana, sarana, dan utilitas perumahan dan permukiman yang dilakukan paling lambat 1 (satu) tahun setelah masa oemeliharaan yang sesuai dengan rencana tata letak yang telah disetujui oleh Pemerintahan Daerah secara bertahap ataupun sekaligus. Seluruh fasilitas sosial dan fasilitas umum yang telah diserahkan kepada Pemerintah Daerah (Pemda) berdasarkan peraturan perundang- 
undangan yang berlaku maka hak, wewenang dan tanggung jawab pengurusannya beralih sepenuhnya kepada Pemda yang bersangkutan.

Jika pengembang, badan usaha swasta dan masyarakat ingin melakukan kerja sama pengelolaan fasilitas yang telah diserahkan kepada Pemda untuk melakukan keperluan melanjutkan pembangunan, maka pengembang diwajibkan memperbaiki dan memelihara fasilitas yang dimaksud dan tidak dapat merubah peruntukn fasilitas-fasilitas tersebut. Pemda selambat-lambatnya dalam waktu 3 (tiga) bulan sejak saat menerima penyerahan, wajib menyerahkan fasilitas sosial dan fasilitas umum yang dimaksud kepada masing-masing instansi yang membidanginya dan membuat Berita Acara Serah Terima.

Pemerintah Daerah menerima penyerahan prasarana,sarana,dan utilitas perumahan dan permukiman yang telah memenuhi persyaratan umum, teknis, dan administrasi. Persyaratan Umum meliputi lokasi sesuai dengan rancangan tata letak yang sudah disetujui oleh Pemerintah Daerah dan sesuai dengan dokumen perizinan dan spesifikasi teknis bangunan. Persyaratan secara teknis, sesuai dengan ketentuan perundang-undangan yang terkait dengan pembangunan perumahan dan permukiman. Persyaratan administrasi yaitu harus memiliki dokumen diantaranya, dokumen rencana tapak yang telah disetujui oleh Pemerintah Daerah, Izin Mendirikan Bangunan (IMB), Izin Pembuatan Pembangunan (IPB), dan surat pelepasan hak atas tanah dari pengembang kepada Pemerintah Daerah.

Pengelolaan prasarana,sarana, dan utilitas yang telah diserahkan kepada Pemerintah Daerah sepenuhnya menjadi tanggung jawab Pemerintah Daerah yang bersangkutan, yang dimana Pemerintah Daerah dapat bekerja sama dengan pengembang, badan usaha swasta atau masyarakat dalam pengelolaannya. Dalam Hal Pemerintahan Daerah melakukan kerja sama tersebut, pemeliharaan fisik dan pendanaan menjadi tanggung jawab pengelola dan pengelola tidak dapat mengubah peruntukan prasarana, sarana, dan utilitas tersebut.

Kewajiban dan tanggung jawab pengembang perumahan terdapat dalam pasal 19 UU No. 1/2011 dinyatakan bahwa penyelenggaraan rumah dan perumahan dilakukan untuk memenuhi kebutuhan rumah sebagai salah satu kebutuhan dasar manusia bagi peningkatan dan pemerataan kesejahteraan rakyat.

Pada dasarnya penyelenggaran perumahan tersebut tidak terlepas dari penyelenggaraan sarana. Berdasarkan Pasal 20 ayat (1) UU No. 1/2011, penyelenggaran perumahan meliputi:

a) perencanaan perumahan;

b) pembangunan perumahan;

c) pengendalian perumahan.

Perumahan yang dimaksud mencakup rumah atau perumahan beserta prasarana, sarana, dan utilitas umum (Pasal 20 ayat (2) UU No. 1/2011). Hal ini juga 
ditegaskan kembali dalam pasal 32 ayat (1) UU No. 1/2011, yang mengatakan bahwa pembangunan perumahan meliputi:

a) pembangunan rumah dan prasarana, sarana, dan utilitas umum; dan/atau

b) peningkatan kualitas perumahan.

Sebagaimana telah dijelaskan di atas bahwa pemakaman merupakan sarana perumahan dan pemukiman, maka pihak yang membangun perumahan tersebut wajib menyediakan sarana pemakaman. Kewajiban adanya sarana ini juga diperlihatkan dalam pasal 42 ayat (1) jo. Pasal 42 ayat (2) UU No. 1/2011 yang mengatakan bahwa rumah tunggal, rumah deret, dan/atau rumah susun yang masih dalam tahap proses pembangunan dapat dipasarkan melalui sistem perjanjian pendahuluan jual beli. Perjanjian jual beli dilakukan setelah memenuhi persyaratan kepastian atas:

a) status kepemilikan tanah;

b) hal yang diperjanjikan;

c) kepemilikan izin mendirikan bangunan induk;

d) ketersediaan prasarana,sarana, dan utilitas umum; dan

e) keterbangunan perumahan paling sedikit $20 \%$ (dua puluh persen).

Berdasarkan uraian diatas, dapat dikatakan bahwa pemakaman sebagai salah satu sarana perumahan dan pemukiman, merupakan suatu kewajiban yang seharusnya diperjanjikan juga oleh pembangun. Dalam pasal 134 UU No. 1/2011, dikatakan bahwa "setiap orang dilarang menyelenggarakan pembangunan perumahan, yang tidak membangun perumahan sesuai dengan kriteria, spesifikasi, persyaratan, prasarana, sarana, dan utilitas umum yang diperjanjikan.

\section{B. UPAYA HUKUM YANG DAPAT DILAKUKAN PENGHUNI PERUMAHAN JIKA PENGEMBANG PERUMAHAN TIDAK MENYEDIAKAN FASILITAS TANAH MAKAM}

Konsumen adalah setiap orang pemakai barang dan/atau jasa yang tersedia dalam masyarakat, baik bagi kepentingan diri sendiri, keluarga, orang lain, maupun makhluk hidup lain. Hak Konsumen adalah hak yang harus dipatuhi oleh para produsen. ${ }^{9}$ Keberadaan konsumen sangat penting bagi suatu keberhasilan dalam usaha, baik dalam perusahaan, ataupun usaha lainnya. Dari tangan konsumenlah kita mendapatkan pundi -pundi uang buah usaha kita atas barang dan jasa yang kita jual atau usahakan.

Hak konsumen wajib diketahui oleh para pebisnis agar para pengusaha atau pebisnis tidak semena - mena dalam memperlakukan konsumen. Jika para pebisnis tidak mematuhinya maka para pebisnis akan mendapatkan ganjaran atau AZ.Nasution, Hukum Perlindungan Konsumen (suatu Pengantar), Diadit Media, Jakarta,
2001,hlm 22 
hukuman tersebut bias sampai ke pengadilan dan yang lebih parah bisa sampai penutupan usaha tersebut.

Kedudukan konsumen terhadap produsen yang seharusnya seimbang menjadi lemah karena rendahnya pengetahuan konsumen akan hak-haknya sebagai konsumen.

Konsumen memiliki berbagai macam hak yang seharusnya diperhatikan dan tidak boleh dilanggar oleh para pelaku usaha. Menurut pasal 4 UU No. 8 tahun 1999 tentang Perlindungan Konsumen tersebut trdapat 9 macam hak yang melekat pada konsumen, tetapi hanya empat hak dasar yang diakui oleh Internasional yaitu:

a) Hak untuk mendapatkan keamanan (the right to safety)

b) Hak untuk mendapatkan informasi (the right to be informed)

c) Hak untuk memilih (the right to choose)

d) Dan Hak untuk didengar (the right to be heard)

Hak-hak konsumen ini perlu diketahui oleh masyarakat luas sebagai konsumen, untuk menjamin kepastian hukum dan perlindungan terhadap konsumen.

Salah satu unsur pokok kesejahteraan rakyat adalah terpenuhinya kebutuhan perumahan, yang merupakan kebutuhan dasar setiap Warga Negara Indonesia dan keluarganya, sesuai dengan harkat dan martabat manusia.

Di samping itu pembangunan perumahan merupakan salah satu instrument terpenting dalam strategi pengembangan wilayah yang menyangkut aspek-aspek yang luas di bidang kependudukan dan berkaitan erat dengan pembangunan ekonomi dan kehidupan sosial dalam rangka pemantapan ketahanan nasional. Dalam pasal 1 angka 2 dan 7 Undang-undang NO. 1 tahun 2011 tentang Perumah dan Permukiman ditentukan bahwa: "Rumah adalah bangunan yang berfungsi sebagai tempat tinggal, atau hunian dan sarana pembinaan keluarga." "Perumahan adalah kelompok rumah yang berfungsi sebagai lingkungan tempat tinggal atau hunian yang dilengkapi dengan prasarana dan sarana lingkungan dimana manusia tinggal dan melangsungkan kehidupannya."

Dapat diketahui bahwa rumah adalah bangunan dimana manusia tinggal dan melangsungkan kehidupannya, disamping itu rumah juga merupakan tempat berlangsungnya proses sosialisasi pada saat seseorang diperkenalkan kepada norma dan adat kebiasaan yang berlaku dalam masyarakat, maka tidaklah mengherankan bila masalah perumahan menjadi masalah yang penting bagi individu. Salah satu faktor utama yang menjadi kelemahan konsumen adalah tingkat kesadaran akan haknya masih sangat rendah, hal ini terutama disebabkan oleh kurangnya kesadaran dari pihak konsumen itu sendiri dan rendahnya pendidikan konsumen yang ada. Oleh karena itu Undang-undang No. 8 tahun 1999 tentang Perlindungan Konsumen ysng ada, dimaksudkan menjadi landasan hukum yang kuat bagi pemerintah dan lembaga perlindungan konsumen swadaya 
masyarakat untuk melakukan pemberdayaan konsumen melalui pembinaan dan pendidikan konsumen.

Upaya yang harus dilakukan Pemerintah yaitu, pemberdayaan konsumen melalui pembentukan Undang-undang yang secara khusus mengatur soal perlindungan konsumen perumahan sehingga dapat melindungi kepentingan konsumen secara integratif dan komprehensif. Secara kelembagaan, Pemerintah melakukan perbaikan atau penyempurnaan peraturan pelaksaanaan, pembinaan aparat, pranata dan perangkat-perangkat yudikatif, administratif dan edukatif, serta sarana dan prasarana lainnya agar nantinya undang-undang tersebut dapat diterapkan secara efektif oleh masyarakat.

Pemerintah perlu lebih berperan dalam menyediakan dan memberikan kemudahan dan bantuan perumahan dan kawasan permukiman bagi masyarakat melalui penyelenggaraan perumahan dan kawasan permukiman yang berbasis kawasan serta keswadayaan masyarakat sehingga merupakan satu kesatuan fungsional dalam wujud tata ruang fisik, kehidupan ekonomi, dan sosial budaya yang mampu menjamin kelestarian lingkungan hidup sejalan dengan semangat demokrasi, otonomi daerah, dan keterbukaan dalam tatanan kehidupan bermasyarakat, berbangsa, dan bernegara.

Pertumbuhan dan pembangunan wilayah yang kurang memperhatikan keseimbangan bagi kepentingan masyarakat berpenghasilan rendah mengakibatkan kesulitan masyarakat untuk memperoleh rumah yang layak dan terjangkau. Perumahan dan kawasan permukiman adalah satu kesatuan sistem yang terdiri atas pembinaan, penyelenggaraan perumahan, penyelenggaraan kawasan permukiman, pemeliharaan dan perbaikan, pencegahan dan peningkatan kualitas terhadap perumahan kumuh dan permukiman kumuh, penyediaan tanah, pendanaan dan sistem pembiayaan, serta peran masyarakat. Perumahan adalah kumpulan rumah sebagai bagian dari permukiman, baik perkotaan maupun perdesaan, yang dilengkapi dengan prasarana, sarana, dan utilitas umum sebagai hasil upaya pemenuhan rumah yang layak huni. Kawasan permukiman adalah bagian dari lingkungan hidup di luar kawasan lindung, baik berupa kawasan perkotaan maupun perdesaan, yang berfungsi sebagai lingkungan tempat tinggal atau lingkungan hunian dan tempat kegiatan yang mendukung perikehidupan dan penghidupan.

Bertitik tolak dari pemahaman akan perlindungan konsumen perumahan, maka dapat dikatakan bahwa: " Perlindungan konsumen perumahan adalah serangkaian upaya yang dibingkai secara hukum, untuk melindungan konsumen perumahan sebagai pengguna fasilitas perumahan, yang meliputi fasilitas bangunan (konstruksi) yang sesuai standar, fasilitas lingkungan, fasilitas sosial, fasilitas umum dan memenuhi standar kesehatan, serta mampu memberi rasa aman kepada penghuninya, baik itu untuk kepentingan pribadi, keluarga, institusi ataupun pihak lain, tetapi tidak untuk diperdagangkan kembali." 
Mengenai hal ini Undang-undang No. 8 tahun 1999 tentang perlindungan konsumen, selanjutnya yang disebut Undang-Undang Perlindungan Konsumen (UUPK) memberikan pengertian tentang perlindungan konsumen secara luas, perlindungan konsumen didefinisikan sebagai segala upaya yang menjamin adanya kepastian Hukum untuk memberikan perlindungan kepada konsumen.

Berdasarkan pasal 3 Undang-undang Perlindungan Konsumen, Perlindungan Konsumen bertujuan untuk :

- Meningkatkan kesadaran, kemampuan, dan kemandirian konsumen untuk melindungi diri sendiri;

- Mengangkat harkat dan martabat konsumen dengan cara menghindarkan dari akses negatif pemakaian barang dan atau jasa;

- Meningkatkan pemberdayaan konsumen dalam memilih, menentukan, dan menuntut hak-haknya sebagai konsumen;

- Menciptakan system perlindungan konsumen yang mengandung unsur kepastian hukum, keterbukaan informasi serta akses untuk mendapatkan informasi;

- Menumbuhkan kesadaran pelaku usaha mengenai pentingnya perlindungan konsumen, sehingga tumbuh sikap jujur dan bertanggung jawab terhadap berusaha;

- Meningkatkan kualitas barang dan atau jasa yang menjamin kelangsungan usaha produksi barang dan atau jasa, kesehatan, kenyamanan, dan keselamatan konsumen.

Hal yang perlu diperhatikan konsumen adalah pada saat serah terima fisik. Rumah yang diserahkan harus cocok spesifikasinya dengan yang ada di dalam perjanjian pengikatan jual beli. Jika tidak sesuai, maka hak konsumen untuk tidak menandatangani berita acara serah terima tersebut sebelum pengembang menyelesaikannya. ${ }^{10}$

Manurut pasal 20 ayat 1 UU 1/2011 pada dasarnya penyelenggaraan perumahan tersebut tidak terlepas dari penyelenggaraan sarana yang meliputi:

a) Perencanaan perumahan;

b) Pembangunan perumahan;

c) Pemanfaatan perumahan; dan

d) Pengendalian perumahan.

Perumahan yang dimaksud mencakup rumah atau perumahan beserta Prasarana, Sarana, dan Utilitas umum. Hal ini juga ditegaskan kembali pada pasal 32 ayat (1) UU 1/2011, yang mengatakan bahwa pembangunan perumahan meliputi:

a) Pembangunan rumah dan prasarana,sarana, dan utilitas umum dan/ atau

b) Peningkatan kualitas perumahan.

10 Kallo Ermin, Perspektif Hukum Dalam Dunia Property, Minerva Athena Pressindo,Jakarta, 2009, hlm 48-50 
Sebagaimana telah dijelaskan diatas bahwa pemakaman merupakan sarana perumahan, dan permukiman, maka pihak yang membangun perumahan tersebut wajib menyediakan tempat pemakaman.

Kewajiban dalam penyediaan tempat pemakaman ini juga diperlihatkan dalam pasal 42 ayat (1) jo. Pasal 42 ayat (2) UU No. 1/2011 yang mengatakan bahwa rumah tunggal, rumah deret / atau rumah susun yang masih dalam tahap proses pembangunan dapat dipasarkan melalui sistem perjanjian pendahuluan jual-beli. Perjanjian pendahuluan jual beli dilakukan setelah memenuhi persyaratan kepastian atas:

a) Status kepemilikan tanah;

b) Hal yang diperjanjikan;

c) Kepemilikan izin untuk mendirikan bangunan induk;

d) Ketersediaan prasarana, sarana, dan utilitas umum; dan

e) Keterbangunan perumahan paling sedikit $20 \%$ (dua puluh persen)

Berdasarkan uraian di atas, dapat dikatakan bahwa pemakaman sebagai salah satu perumahan dan permukiman, merupakan suatu kewajiban yang seharusnya diperjanjikan juga oleh si pembangun / pengembang. Dalam pasal 134 UU No. 1/20011, dikatakan bahwa setiap orang dilarang menyelenggarakan pembangunan perumahan yang tidak membangun perumahan sesuai dengan kriteria, spesifikasi,persyaratan, prasarana, sarana, dan utilitas umum yang diperjanjikan.

Kewajiban pengembang perumahan untuk menyediakan tempat pemakaman diatur juga dalam Peraturan Daerah (PERDA) atau peraturan kepala daerah. Hal ini dapat dilihat dalam Peraturan Bupati Sidoarjo No. 44 tahun 2011 tentang Kewajiban Pengembang Perumahan Menyediakan Tanah Makam ("Pergub 44/2011"). Pasal 1 Pergub 4/2011 mengatakan bahwa: " Setiap pengembang perumahan wajib menyediakan tanah makam. Luas tanah makam tersebut adalah $2 \%$ dari luas perumahan yang tercantum dalam Keputusan Bupati Sidoarjo terkait persetujuan rencana tapak (site plan) perumahan tersebut.

Dalam hal ini terdapat suatu janji oleh pembangun perumahan yang dinyatakan dalam iklan atau promosi penjualan dengan pernyataan bahwa perumahan tersebut akan dilengkapi dengan sarana pemakaman, tidak direalisasikan, maka secara hukum pembangun perumahan tersebut telah melanggar Pasal 8 ayat (1) Undang-Undang No. 8 Tahun 1999 tentang Perlindungan Konsumen (“UU Perlindungan Konsumen”).

Pasal 8 ayat (1) huruf f UU Perlindungan Konsumen mengandung suatu ketentuan yang menyatakan bahwa pelaku usaha dilarang untuk memproduksi atau memperdagangkan barang dan/atau jasa yang tidak sesuai dengan janji yang dinyatakan dalam label, etiket, keterangan, iklan atau promosi penjualan barang dan atau jasa. Berdasarkan Pasal 62 ayat (1) UU Perlindungan Konsumen, pelaku usaha yang melanggar ketentuan Pasal 8 UU Perlindungan Konsumen dapat 
dipidana penjara paling lama 5 (lima) tahun atau pidana denda paling banyak Rp2.000.000.000,00 (dua miliar Rupiah).

Selain itu, berdasarkan Pasal 45 ayat (1) UU Perlindungan Konsumen, dalam hal terdapatnya kerugian akibat tindakan dari pelaku usaha, maka Anda selaku konsumen dapat mengajukan gugatan kepada pengembang melalui lembaga yang bertugas menyelesaikan sengketa antara konsumen dan pelaku usaha atau melalui peradilan yang berada di lingkungan peradilan umum.

Prestasi merupakan kewajiban yang harus dipenuhi para pihak dalam suatu kontrak. ${ }^{11}$ Para Ahli Hukum lain seperti Subekti berpendapat bahwa prestasi merupakan barang sesuatu yang dapat dituntut. ${ }^{12}$

Wanprestasi menurut bahasa hukum dapat diartikan apabila seseorang yang berjanji terhadap orang lain dalam perjanjian tidak melakukan prestasinya. Wanprestasi atau tidak dipenuhinya janji.Dalam suatu perjanjian, adakalanya salah satu pihak tidak memenuhi kewajiban sebagaimana yang tercantum dalam perjanjian tersebut. Dalam hukum, perbuatan semacam ini biasa disebut sebagai kelalaian (wanprestasi). Wanprestasi adalah tidak memenuhi atau lalai melaksanakan kewajiban sebagaimana yang ditentukan dalam perjanjian yang dibuat antara kreditur dengan debitur. Menurut kamus Hukum, Wanprestasi berarti kelalaian, kealpaan, cidera janji, tidak menepati kewajibannya dalam perjanjian.Wanprestasi adalah suatu keadaan dimana seorang debitur (berutang) tidak memenuhi atau melaksanakan prestasi sebagaimana telah ditetapkan dalam suatu perjanjian.Perjanjian memiliki kekuatan mengikat (Pasal 1339 KUH Perdata) sehingga pihak yang dirugikan oleh adanya wanprestasi ini dapat melayangkan tuntutan atas kelalaian yang terjadi. Pihak yang dirugikan dapat melakukan tuntutan dengan salah satu cara sebagaimana yang disebutkan dalam Pasal 1267 KUH Perdata, yaitu:

- Pemenuhan perikatan

- Pemenuhan perikatan dengan ganti kerugian

- Ganti kerugian

- Pembatalan perjanjian timbal balik

- Pembatalan dengan ganti kerugian

Ganti rugi yang diharapkan bisa berupa biaya yang dikeluarkan, biaya yang diakibatkan atas kerugian dan perkiraan keuntungan yang hilang akibat timbulnya kelalaian tersebut. Pembayaran ganti rugi ini harus didahului oleh surat resmi dari pihak yang dirugikan (mengenai kelalaian yang terjadi) terhadap pihak yang lalai.

\footnotetext{
11 Miru Ahmadi, Hukum Kontrak Dan Perancangan Kontrak, PT.Raja Grafindo Persada, Jakarta, 2007, hlm. 68

${ }^{12}$ Subekti. R, Hukum Perjanjian, Cetakan VI, Intermasa, Jakarta, 1979, hlm 45
} 
Upaya hukum yang dapat dilakukan apabila pengembang perumahan wanprestasi atau tidak dipenuhinya akan janji atas penyediaan tempat pemakaman yang dapat dilakukan warga perumahan tersebut adalah menanyakan terlebih dahulu, prinsipnya adalah upayakan untuk menempuh penyelesaian permasalahan ini secara baik-baik. Jika tidak didapat titik temu dalam upaya perundingan tersebut, warga perumahan dapat melayangkan teguran/somasi terlebih dahulu yang isinya mengingatkan pengembang perumahan harus melaksanakan kewajibannya sampai batas waktu yang telah disepakati. Apabila waktu yg telah diperjanjikan terlewati, warga perumahan yang hak atas tempat pemakan tersebut belum terpenuhi, dapat memberikan tenggat waktu kepada pengembang perumahan untuk memenuhi kewajibannya. Jika pengembang perumahan bergeming, warga perumahan tersebut dapat menempuh jalur hukum dengan menggugat pelaku usaha dan sekaligus melaporkan pengembang perumahan secara pidana.

Gugatan dapat dilakukan melalui lembaga penyelesaian sengketa pelaku usaha konsumen yaitu Badan Penyeesaian Sengketa Konsumen (BPSK) atau ke Peradilan Umum. Di Peradilan Umum gugatan dilayangkan atas dasar wanprestasi atau ingkar janjinya pihak pengembang perumahan. Dalam gugatan ini, warga perumahan yang tidak terpenuhi hak atas tempat pemakanam dapat menuntut ganti rugi dan juga bunga berupa hilangnya keuntungan yang sudah diperkirakan atau dibayangkan oleh kreditor seandainya tidak terjadi wanprestasi.

Secara pidana, dapat juga melaporkan pengembang perumahan dengan tuduhan melanggar pasal 8 ayat (1) huruf F Undang-undang No. 8 tahun 1999 tentang Perlindungan Konsumen ("UU Konsumen”). Pasal ini pada intinya melarang pelaku usaha untuk memperdagangkan barang yang tidak sesuai dengan janji yang dinyatakan dalam label, etiket, keterangan, iklan, atau promosi penjualan barang tersebut. Dalam kasus ini, pengembang perumahan membangun tidak sesuai dengan ketentuan spesifikasi bangunan yang terdapat dalam brosur dan yang telah dijanjikan sebelumnya. Pelaku usaha yang melanggar ketentuan tersebut terancam sanksi pidana paling lama 5 tahun atau denda maksimal dua (2) milyar rupiah. Ancaman sanksi ini termuat dalam pasal 62 UU Konsumen. Ancaman pidana lain bagi pengembang perumahan yang membangun perumahan yang tidak sesuai dengan kriteria, spesifikasi, dan persyaratan yang diperjanjikan juga diatur dalam pasal 134 jo. Pasal 151 Undang-undang pasal No. 1 tahun 2011 tentang Perumahan dan Kawasan Permukiman ("UU Perumahan"), yaitu denda maksimal 5 milyar rupiah.

Selain sanksi denda, pengembang perumahan tersebut juga dapat dijatuhi sanksi administratif sebagaimana terdapat dalam pasal 150 UU Perumahan. Sanksinya mulai dari peringatan tertulis, pencabutan izin usaha, hingga penutupan lokasi. 


\section{KESIMPULAN}

a. Pelaksanaan pengadaan fasilitas sosial dan fasilitas umum telah dipenuhi oleh pengembang. Tetapi tidak semua pengembang memenuhi hal tersebut dikarenakan pengadaan fasilitas sosial dan fasilitas umum memang tidak diatur dalam Perjanjian Pengikatan Jual Beli (PPJB), Pengadaan tersebut merupakan suatu syarat wajib yang harus disediakan oleh pihak pengembang perumahan untuk mendapatkan izin mendirikan bangunan (IMB) dari Dinas Tata Ruang dan Bangunan.

b. Upaya hukum yang dapat dilakukan apabila pengembang perumahan wanprestasi atau tidak dipenuhinya akan janji atas penyediaan tempat pemakaman yang dapat dilakukan warga perumahan tersebut adalah menanyakan terlebih dahulu, prinsipnya adalah upayakan untuk menempuh penyelesaian permasalahan ini secara baik-baik. Jika tidak didapat titik temu dalam upaya perundingan tersebut, warga perumahan dapat melayangkan teguran/somasi terlebih dahulu yang isinya mengingatkan pengembang perumahan tersebut harus melaksanakan kewajibannya sampai batas waktu yang telah disepakati. Apabila waktu yg telah diperjanjikan terlewati, warga perumahan yang hak atas tempat pemakan tersebut belum terpenuhi, dapat memberikan tenggat waktu kepada pengembang perumahan untuk memenuhi kewajibannya. Kalau pengembang perumahan tersebut bergeming, warga perumahan tersebut dapat menempuh jalur hukum dengan menggugat pelaku usaha dan sekaligus melaporkan pengembang perumahan tersebut secara pidana.

\section{SARAN}

a. Pengadaan dan pengelolaan fasilitas sosial dan fasilitas umum sebaiknya diatur dalam perjanjian perikatan jual beli (PPJB) apabila terjadi wanprestasi oleh pengembang perumahan, pihak pembeli/pemakai dapat menuntut pihak pengembangan perumahan tersebut dengan menggunakan PPJB tersebut.

b. Fasilitas sosial dan fasilitas umum pada kawasan perumahan dan permukiman yang telah selesai pembangunannya sebaiknya diserahkan oleh pengembang perumahan kepada Pemerintah sehingga pengelolaan atas fasilitas-fasilitas tersebut menjadi tanggung jawab pemerintah sepenuhnya. Apabila telah diserahkan kepada Pemerintah melalui Surat Ketetapan Pajak Daerah (SKPD) terkait harus melakukan pengelolaan secara baik. 


\section{Buku-Buku Literatur}

\section{Daftar Pustaka}

Ajiraksa, 2002, Perencanaan dan Pengembang perumahan, PT. Citra Aditya Bakti.

Alwi,Hasan, 2003, Kamus Besar Bahasa Indonesia, Jakarta : Balai Sarbini. AZ.Nasution,2001, Hukum Perlindungan Konsumen (suatu Pengantar), Diadit Media, Jakarta

Ibrahim Johny, 2005, Teori dan Metode Penelitian Hukum Normatif, Malang, Bayumedia publishing.

Kallo Ermin, 2009, Perspektif Hukum Dalam Dunia Property, Minerva Athena Pressindo, Jakarta.

Miru Ahmadi, 2007, Hukum Kontrak Dan Perancangan Kontrak, Jakarta, PT.Raja Grafindo Persada.

Soimin Soedharyo, 2008, Status Hak dan Pembebasan Tanah, PT. Sinar Grafika.

Subekti. R, 1979, Hukum Perjanjian, Intermasa, Jakarta.Cetakan VI,

Sudaryatmo, 1999, Hukum dan Advokasi Konsumen, Bandung: Citra Adithya Bakti.

Perencanaan dan Pembangunan perumahan. 2006

\section{Peraturan Perundangan}

Peraturan Pemerintah Nomor 9 tahun 1987 tentang Penyediaan Penggunaan Tanah untuk keperluan tempat pemakaman.

Peraturan Pemerintah Nomor 9 tahun 2009 tentang Pedoman Penyerahan Prasarana,Sarana, dan Utilitas Perumahan dan Pemukiman di Daerah.

Peraturan Bupati Sidoarjo Nomor 44 tahun 2011 tentang Kewajiban Pengembang Perumahan Menyediakan Tanah Makam.

Undang-undang Nomor 8 tahun 1999 tentang perlindungan konsumen.

Undang-Undang Nomor 1 tahun 2011 tentang Perumahan dan Kawasan Pemukiman.

\section{Jurnal}

Soedjajadi Keman, 2005, Kesehatan Perumahan dan dan Lingkungan Pemukiman, Jurnal Kesehatan Lingkungan, Fakultas Kesehatan Masyarakat Univ. Airlangga, Vol.2, No. 1 